\title{
Orobanche rumseiana A. Pujadas \& P. Fraga (Orobanchaceae), a new species from the Balearic Islands
}

\author{
Antonio J. Pujadas-Salvà \& Pere Fraga I Arguimbau
}

\begin{abstract}
PUJADAS-SALVÀ, A. J. \& P. FRAGA I ARGUIMBAU (2012). Orobanche rumseiana A. Pujadas \& P. Fraga (Orobanchaceae), a new species from the Balearic Islands. Candollea 67: 65-74. In English, English and French abstracts.

A new species, Orobanche rumseiana A. Pujadas \& P. Fraga (subgen. Trionychon (Wallr.) Spach, Orobanchaceae) is described from Majorca and Minorca, Balearic Islands. The new species inhabits coastal rocky areas with shrubby vegetation, is parasitic on Rosmarinus officinalis L. It is characterised by an inflorescence with erect-patent to patent flowers, a calyx with long acuminate triangular teeths, a corolla tube uniformly curved, corolla lobes obtuse with a distinctive mucro, some staminal filaments pubescent in the lower half and hairy anthers. Its morphological traits, and the fact that it is a parasite of Rosmarinus officinalis L., relate it to Orobanche rosmarina Beck with which it has been misidentified. It is also related to Orobanche mariana A. Pujadas and Orobanche pseudrosmarina A. Pujadas \& Muñoz Garm. A detailed description and diagnosis are provided. Morphological characters that allow it to be discriminated from these related taxa are discussed and summarized.
\end{abstract}

\section{Key-words}

OROBANCHACEAE - Orobanche - Balearic Islands Taxonomy

\begin{abstract}
Résumé
PUJADAS-SALVÀ, A. J. \& P. FRAGA I ARGUIMBAU (2012). Orobanche rumseiana A. Pujadas \& P. Fraga (Orobanchaceae), une nouvelle espèce des Iles Baléares. Candollea 67: 65-74. En anglais, résumés anglais et français. Une nouvelle espèce, Orobanche rumseiana A. Pujadas \& P. Fraga (subgen. Trionychon (Wallr.) Spach, Orobanchaceae) est décrite de Majorque et Minorque des Iles Baléares. La nouvelle espèce habite les zones côtières rocheuses et est un parasite de Rosmarinus officinalis L. Elle est caractérisée par une inflorescence à fleurs dressées à étalées, un calice pourvu de dents triangulaires longuement acuminées, un tube de la corolle uniformément courbé, une corolle à lobes obtus et mucronés, des filaments staminaux pubescents dans leur moitié inférieure et des anthères velues. Ses caractéristiques morphologiques et son parasitisme de Rosmarinus officinalis L. la rapprochent d'Orobanche rosmarina Beck avec laquelle elle a d'ailleurs été confondue. Elle est aussi proche d'Orobanche mariana A. Pujadas et d'Orobanche pseudorosmarina A. Pujadas \& Muñoz Garm. Une description détaillée et une diagnose sont proposées. Les caractères morphologiques qui permettent de la séparer des taxons proches sont discutés et résumés.
\end{abstract}

Addresses of the authors: AJPS: Departamento de Ciencias y Recursos Agrícolas y Forestales, Jardín Botánico-Universidad de Córdoba, Apdo. 3048,14080 Córdoba, Spain. Email: cr1pusaa@uco.es

PFIA: Consell Insular de Menorca, Plaça de la Biosfera, 5, 07703 Maó, Menorca, Balearic Islands, Spain. 


\section{Typification}

Orobanche L. (Orobanchaceae) is a complex genus highly diversified in the Iberian Peninsula and Balearic Islands, but several authors have reported different numbers of recognized taxa. Foley (2001b) recognizes up to 32 taxa, while PUJADASSALVÀ (2002) reports 39 taxa. Recent studies have helped improve knowledge of the taxonomy of the subgenus Trionychon (Wallr.) Spach (Pujadas-Salvà \& CRespo, 2004; CARLÓN \& al., 2005; PuJadAs-SALVÀ, 2006; Pujadas-Salvà, 2007; CARlón \& al., 2008; Pujadas-Salvà \& MuñozGARMENDIA, 2010).

Previously, individuals of Orobanche from the Eastern Balearic Islands (Majorca and Minorca) collected by Fred Rumsey on Majorca (growing on Rosmarinus officinalis L.) and by Pons y Guerau in Minorca (with no indication of the host) were determined as $O$. rosmarina Beck by BECKETT (1993: 148), Foley (2001b: 40, 42) and CARLÓN \& al. (2008: 73). There are no other references in literature to the presence of this taxon in the Balearic Islands (BARCELÓ I COMBIS, 18791881; MARÈs \& VigINEIX, 1880; RodRíGUEZ-FEMENÍAS, 1904; KNOCHE, 1922; Greuter \& al., 1989; Bolòs \& ViGO, 1996; Gil \& Llorens, 1999; Rosselló \& SÁez, 2000; PujadasSalvì, 2001; Fraga i Arguimbau \& al., 2004).

Recent studies have shown that not all Orobanche growing on Rosmarinus officinalis belong to Orobanche rosmarina. Thus, $O$. mariana A. Pujadas and O. pseudorosmarina A. Pujadas \& Muñoz Garm., despite sharing certain similarities with $O$. rosmarina, can be easily distinguished from the latter due to their morphological traits and have subsequently been described as different taxa (cf. PuJAdAs-SAlvÀ, 2007; PuJADAs-SAlvì \& MuÑOZ-GARMENDIA, 2010). Consequently, the plants from the Balearic Islands may have also been included in $O$. rosmarina due to the lack of a detailed analysis of their morphology and other differences with respect to better known and accepted species.

In fact, $O$. rosmarina was recently lectotypified by FOLEY (2001a: 231) using specimens collected by Welwitsch in Estremadura (Portugal) labelled as Trionychium rosmarinum Welw. in its distributed exsiccatae. Furthermore, available herbarium material of $O$. rosmarina is relatively scarce for comparison with known populations of Orobanche growing on Rosmarinus L. This may be one of the main reasons why any plant of the Orobanche subgen. Trionychon found as a parasite on Rosmarinus is commonly identified as $O$. rosmarina. However, as stated by Foley (2001a, 2001b) and PUJADASSALVÀ \& al. (2005), some records of $O$. rosmarina may be erroneous determinations.

A detailed analysis of the lectotype established by FOLEY (2001a: 231) for O. rosmarina Beck compared with the plants collected on Majorca and Minorca has revealed significant and consistent morphological differences between them, enough to consider the latter at a different taxonomic level; hence, in this study populations from the Balearic Islands are proposed as a new species.

\section{Material and Methods}

Studies were made of both fresh material collected from native populations and dried specimens from the COA and "H. Fraguense" herbaria. Detailed determinations of the plants were made through morphological characterisation of the Balearic plants compared with O. rosmarina as described by FOLEY (2001a: 231), and also after a careful study of both the single specimen of Foley's lectotype (BM [574992]) and plants from its traditional location (Serra da Arrábida, Estremadura, Portugal), parasitic on Rosmarinus officinalis, collected by Welwistch and Guimarães and kept at the LISU herbarium, and also those collected later by Rothmaler and kept at JE. The description and figures published by FOLEY (2001b: 40-41) were also considered.

The morphological traits of the plants from the Balearic Islands were compared with the other two species of subgen. Trionychon that parasitize Rosmarinus, namely Orobanche mariana and $O$. pseudorosmarina, using specimens deposited at COA, $\mathrm{W}$ and $\mathrm{WU}$ herbaria.

A critical review was also made of specimens kept at various herbaria (ABH, BC, BCN, BM, COA, COFC, COI, HJBS, JACA, JE, LISI, LISU, MA, MAF, MGC, MPU, MUB, SEV, $\mathrm{UIB}, \mathrm{VAB}$ and VAL), as well as a number of private herbaria on the Balearic Islands ("H. Col.legi Oficial de Farmacèutics de les Illes Balears", "H. Fraguense", "H. Orell-Casasnovas") in order to compare and determine the area of distribution.

The biogeographic and bioclimatic aspects are based on Rivas-MARTíneZ \& al. (2001). The authors of syntaxon names follow the standardisation by RIVAS-MARTíNEZ \& al. (2002).

According to Crespo \& Pujadas-Salvà (2006), Domina $\&$ RAAB-STRAube (2010) and Domina (2010), taxa of the subgenus Trionychon are included under the genus Orobanche.

\section{Results}

Orobanche rumseiana A. Pujadas \& P. Fraga, spec. nova (Fig. 1, 2).

Typus: SPAIN. Balearic Islands, Majorca: Pollença, Cala Sant Vicenç, c. Punta de Ses Coves Blanques, 31SEE0419, $103 \mathrm{~m}$, parasitic on Rosmarinus officinalis, 2.V.2003, A. Pujadas s.n. (holo-: COA [49186]; iso-: BM, G, MA). Planta humilis, (7-)10-26(-35) cm alta. Caulis gracilis, ad medium 2-4,5 mm latus. Inflorescentia 5,5-15(-19) $\times 2,3-$ $3 \mathrm{~cm}$, cylindracea, rotundata in apice, obtusa, rare subobtusa; rhachis dense pubescente-glandulosa, cum pilis 0,2- 


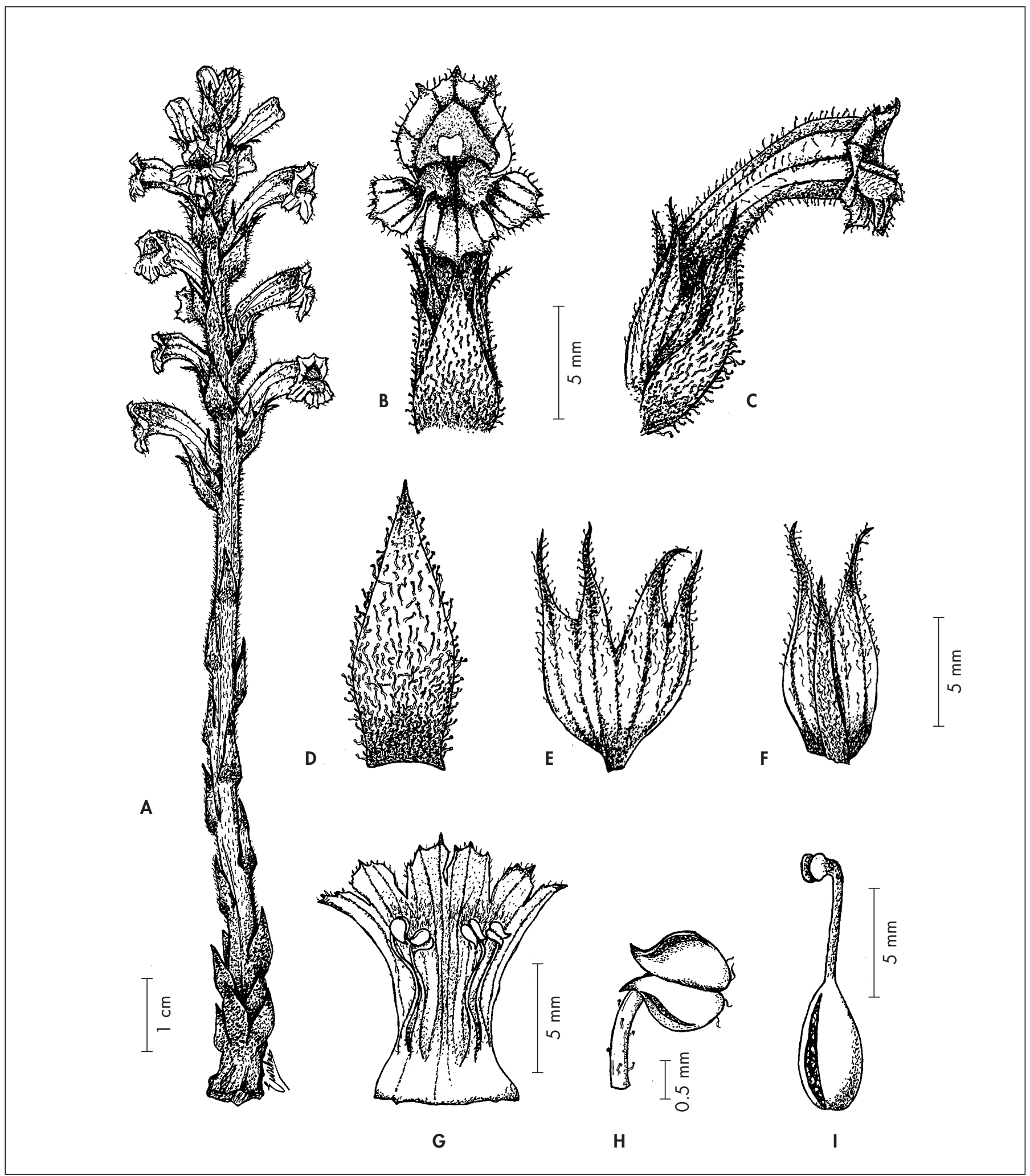

Fig. 1. - Orobanche rumseiana A. Pujadas \& P. Fraga. A. Appearance; B. Flower, front view; C. Flower, side view; D. Bract; E. Open calyx; F. Calyx, side view and bracteole; G. Open corolla and androecium; H. Anther; I. Gynoecium.

[A. Pujadas s.n., COA] 


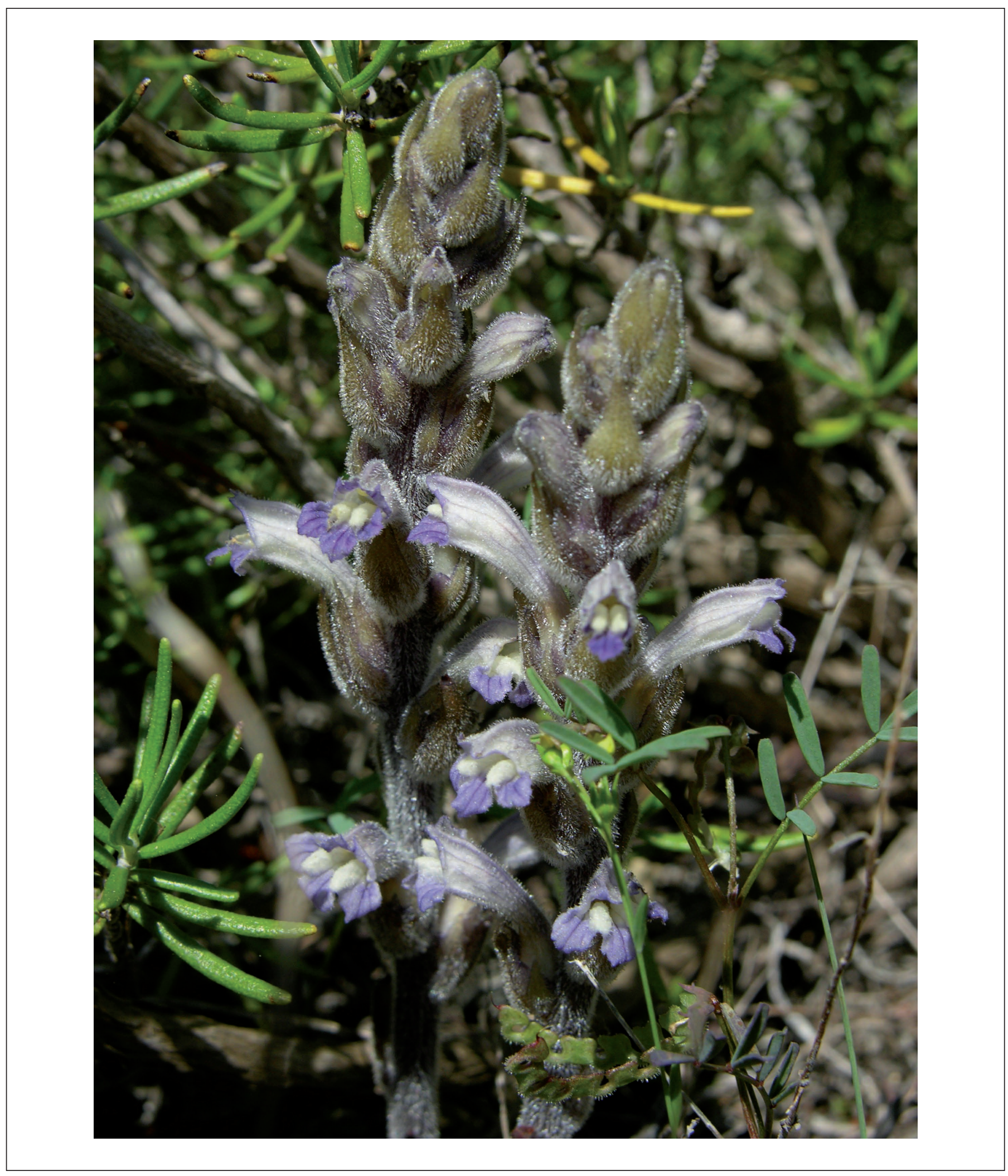

Fig. 2. - Orobanche rumseiana A. Pujadas \& P. Fraga.

[Photo by the authors] 
0,6 mm longis. Bracteae 7-12 $\mathrm{mm}$ longae, cum pilis glandulosis 0,1-0,5 mm longis. Bracteolae 4-7,5 $\times$ 0,7-1,5 mm, linear-lanceolatae. Calyx (6,5-)8-11,5 mm longus, dentibus triangularibus longiacuminatibus; dense piloso-glandulosus, cum pilis 0,1-0,5 mm. Corolla (14-)15$18 \mathrm{~mm}$ longa, lobis obovatis, obtusis; apex loborum mucronatus (mucro usque ad 0,5 mm); corollae labiorum marginibus breviglanduloso-pilosis (ciliatis), pilis usque ad 0,3 mm. Filamenta staminales pubescentes, cum pilis 0,1-0,4 mm infra dimidium, et supra pilis glandulosis (ca. $0,1 \mathrm{~mm}$ ) subsessilibus, sparsis infra antheras. Antherae 1,1-1,3 mm longae, pilosae ad basim, sparsis pilis $\leq 0,6 \mathrm{~mm}$, interdum cadentibus. Ovarium, sicut stylus, glabrum. Parasita supra Rosmarini officinalis radices.

Small plant, (7-)10-26(-35) cm high; stem 2-4.5 mm in diameter at medium height, only slightly thickened or clavate at the base with a diameter of (5-)7-15 mm, simple, rarely branched below ground, sometimes with sterile buds at the base, densely pubescent, indumentum of glandular hairs 0.2$0.6 \mathrm{~mm}$ long, hyaline, gland yellow or ferruginous when dry, glabrous in the lower part, stem colour whitish, usually tinged purple, becoming brown tinged dark blue when dry; basal leaves 3-13 $\times(2-) 3-5 \mathrm{~mm}$, sparse, deltoid to lanceolate, glabrous, upper leaves 5-12 $\times 2-4 \mathrm{~mm}$, lanceolate to widely lanceolate, minutely pubescent with glandular hairs 0.1 $0.3 \mathrm{~mm}$ long, indumentum dense at the base, lax towards the apex; inflorescence 5.5-15(-19) $\times 2.3-3 \mathrm{~cm}$, dense to subdense, cylindrical, rounded apex, obtuse or rarely subobtuse; rachis with a dense indumentum of hyaline glandular hairs 0.2 $0.6 \mathrm{~mm}$ long, hair glands yellow or ferruginous when dry, rachis colour whitish tinged purple, becoming brown tinged deep blue when dry; flowers sessile, only sometimes the lower ones with a short peduncle up to $3 \mathrm{~mm}$ long; bracts (6-)7-12 $\times 2.5-3.5 \mathrm{~mm}$, shorter than calyx, ovate to ovate-lanceolate, pubescent with hyaline glandular hairs $0.1-0.5 \mathrm{~mm}$ long, glands yellow or ferruginous when dry, indumentum dense, laxer towards the apex, deep purple when dry; bracteoles 4-7.5 $\times$ 0.7-1.5 mm, linear-lanceolate, purple or whitish tinged purple, deep purple or somewhat purplish blue when dry, rarely brown; calyx (6.5-)8-11.5 mm long, with 4 triangular teeth, long acuminate, equalling the tube, lacking a fifth adaxial tooth, veins somewhat marked, calyx segments connate, abaxialy up to $3.5 \mathrm{~mm}$ high, adaxialy up to $1.5 \mathrm{~mm}$ high, not overlapping, indumentum of glandular hairs dense and uniform in the upper half, laxer towards the base, hairs 0.1-0.6 mm long, calyx segments purplish blue, deeper purple blue when dry; corolla (14-)15$18 \mathrm{~mm}$ long, bilabiate, erect-patent to patent, dorsal line uniformly curved, tubulose, base slightly inflated becoming narrow above stamen insertion, 1.7-2.4 mm wide, slightly infundibiliform towards the apex, $3.5-5 \mathrm{~mm}$ wide at the mouth, shortly pubescent with glandular and eglandular hairs (up to $0.2 \mathrm{~mm}$ ) at the base, with eglandular and some glandular hairs (up to $0.3 \mathrm{~mm}$ ) in the lower half, and predominantly with glandular hairs and some eglandular hairs $(0.1-0.5 \mathrm{~mm})$ in the upper half (glandular hairs hyaline, with glands hyaline or ferruginous when dry in all cases), corolla glabrous inside except at the throat folds with papillate hairs up to $0.3 \mathrm{~mm}$, corolla colour whitish towards the base, often slightly tinged purple, purplish blue with deep purple veins above the filaments insertion, lobes blue to bluish-purple, becoming purplish blue when dry, upper lip bilobed, slightly emarginated, lobes with rounded apex, obtuse, with a central mucro up to $0.7 \mathrm{~mm}$ long, lower lip with subequal lobes or central one slightly bigger than laterals, obovate, obtuse, with a central mucro up to $0.5 \mathrm{~mm}$ long, margins erose, shortly ciliate with glandular hairs 0.1-0.4 mm long; stamen filaments inserted sub-horizontally, the adaxial ones to $4-5 \mathrm{~mm}$ from corolla base, the abaxial ones to $3.5-4.5 \mathrm{~mm}$, both with hairs $0.1-0.4 \mathrm{~mm}$ long in the lower half and with sparse subsessile glandular hairs (ca. $0.1 \mathrm{~mm}$ ) below the anthers, filaments white; anthers 1.1-1.3 mm long (including apiculus ca. $0.2 \mathrm{~mm}$ ), ovate, apiculate, with sparse long hairs $\leq 0.6 \mathrm{~mm}$ at the base, hairs sometimes deciduous, anthers white, even when dry; ovary glabrous, purplish blue or whitish tinged purple; style glabrous, pale purplish; stigma scarcely bilobed, yellowish white; parasite on roots of Rosmarinus officinalis.

Ecology and phytosociology. - On Majorca, Orobanche rumseiana grows on a karstic, slightly sloped, rocky plateau close to the coast with a moderate influence of sea spray. It can be found in Smilaco balearicae-Ampelodesmetum mauritanicae Rivas-Martínez 1992 (alliance Oleo-Ceratonion siliquae Guinochet \& Drouineau 1944; order Pistacio lentisciRhamnetalia alaterni Rivas-Martínez 1975; class Quercetalia Ilicis Molinier 1934) (sensu RIVAS-MARTíneZ \& al., 2001), a Mediterranean shrubby vegetation that grows in sunny, poor soils. In Minorca, the species is more widely distributed (Fig. 3) and although it can only be found near to the coast, it has also been observed mainly in two plant communities: in Loto tetraphylli-Ericetum multiflorae O. Bolòs \& Moliner 1958 (alliance Rosmarinion officinalis Molinier 1934; order Rosmarinetalia officinalis Molinier 1934; class Rosmarinetea officinalis Rivas-Martínez \& al. 1991) (sensu RIVAS-MARTínEZ $\&$ al., 2001) in limestone soils mostly originating from Quaternary fossil dunes; and in Ampelodesmo mauritanicaeEricetum scopariae O. Bolòs \& al. 1970 (alliance Ericenion arboreae Rivas-Martínez \& al. 1986; order Pistacio lentisciRhamnetalia alaterni Rivas-Martínez 1975; class Quercetalia Ilicis Molinier 1934) (sensu Rivas-MARTínez \& al., 2001) in siliceous sandy soils. Both plant associations are linked to vegetation in relatively low shrub-lands and open spaces. In all cases, it parasitizes on Rosmarinus officinalis.

Distribution, bioclimatology and biogeography. - Orobanche rumseiana is only known to grow in the Eastern Balearic Islands. It should be currently regarded as a stenochorous endemism of the coastal ecosystems where it grows in a reduced and 


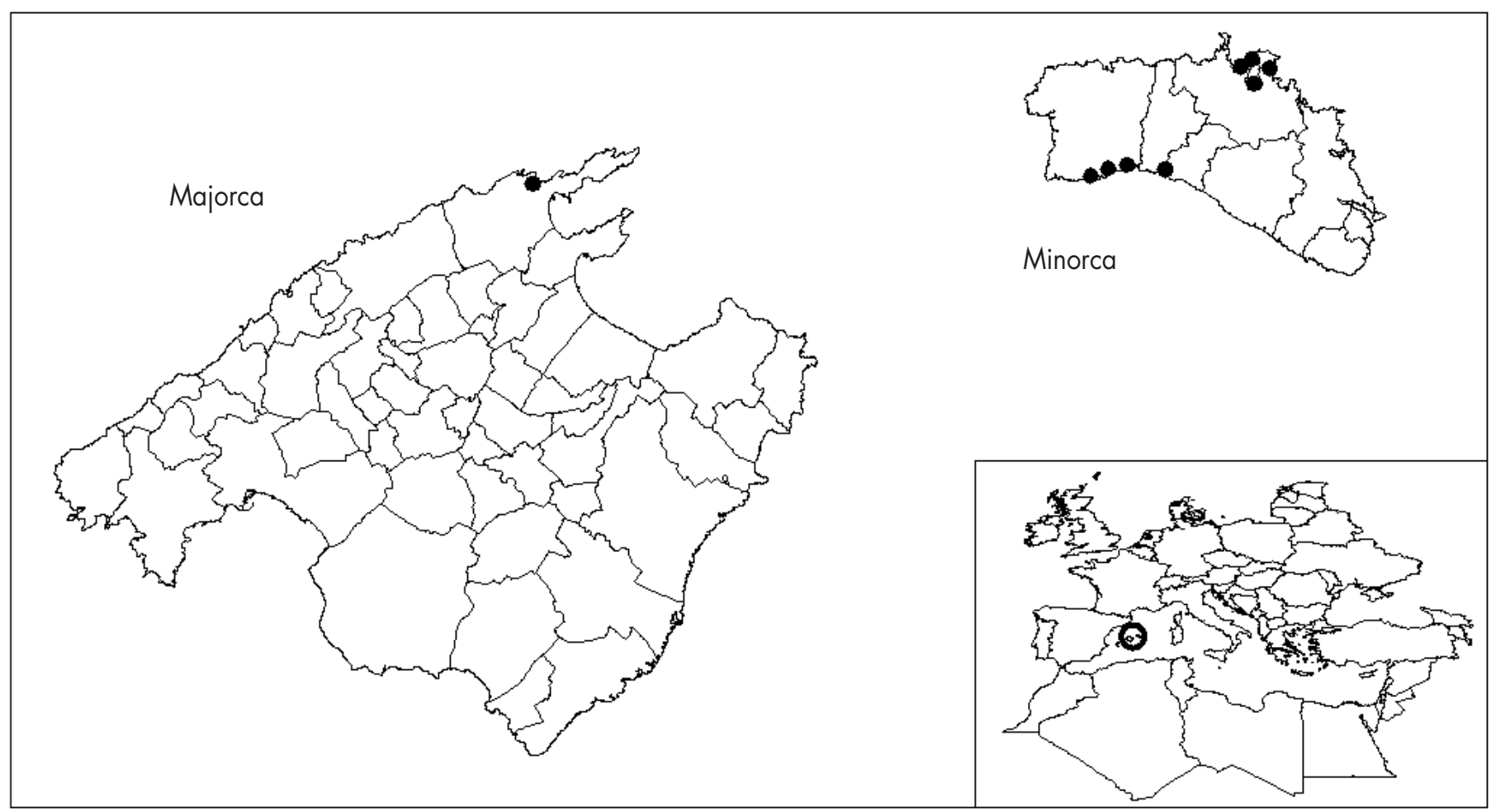

Fig. 3. - Distribution of Orobanche rumseiana A. Pujadas \& P. Fraga in Balearic Islands.

discontinuous area, on Majorca in the north, in Serra de Tramuntana, near Cala Sant Vicenç, Pollença, but it was also reported by F. Rumsey in Alcudia; and in Minorca it is always found near to the coast (normally less than $500 \mathrm{~m}$ from the sea) but is more widely distributed in the north and south of the island, with at least six recorded populations (Fig. 3). On this island, all attempts to locate this species in apparently favourable inland habitats have failed.

It grows in Mediterranean pluviseasonal-oceanic bioclimates, in territories in the Thermo-Mediterranean stage. From a biogeographic standpoint, it is included in the Balearic-CatalanProvençal Province, Balearic Subprovince, Minorcan and Majorcan Sectors (sensu Rivas-MARTínez \& al., 2002), with a typically Mediterranean maritime climate characterised by mild and rather rainy winters and very hot and dry summers. The drought period normally lasts six or more months. It grows from 2 to $105 \mathrm{~m}$ above sea level. The flowering period is quite long, lasting from April to early June.

Etymology. - The epithet "rumseiana" named after Fred Rumsey (BM) who showed the authors the place on Majorca where the new species grows.

Conservation status and proposals. - In the last ten years, the known population of $O$. rumseiana on Majorca has undergone important variations in plant number. Census figures vary, with as many as 30 individuals having been recorded in the most favourable years, compared with no plants or only a few isolated individuals in other years. Even if other populations exist, e.g. in Alcudia, as indicated by Rumsey, it is highly likely that these would also display similar variations in plant number from one year to another. Populations on Minorca seem to be more constant in terms of plant number, at least in the last five years.

It is likely that some populations on both islands have been destroyed by urban development, particularly in coastal areas.

Moreover, a large population of feral goats has been detected on Majorca in the area of Coves Blanques, exerting strong herbivorous pressure on vegetation. It seems that goats look for Orobanche due to its juicy stem and grazed plants have been observed in this area.

For this reason, and due to the increasing pressure of negative human activities in recent decades, we propose that this new species be classified as Vulnerable (VU) according to IUCN (2001) criteria.

Although all the known populations are found in areas with some type of legal protection against urban development, at regional level as is the case of the Natural Areas of Special Interest (ANEI) in the Balearic Islands, or even at European 


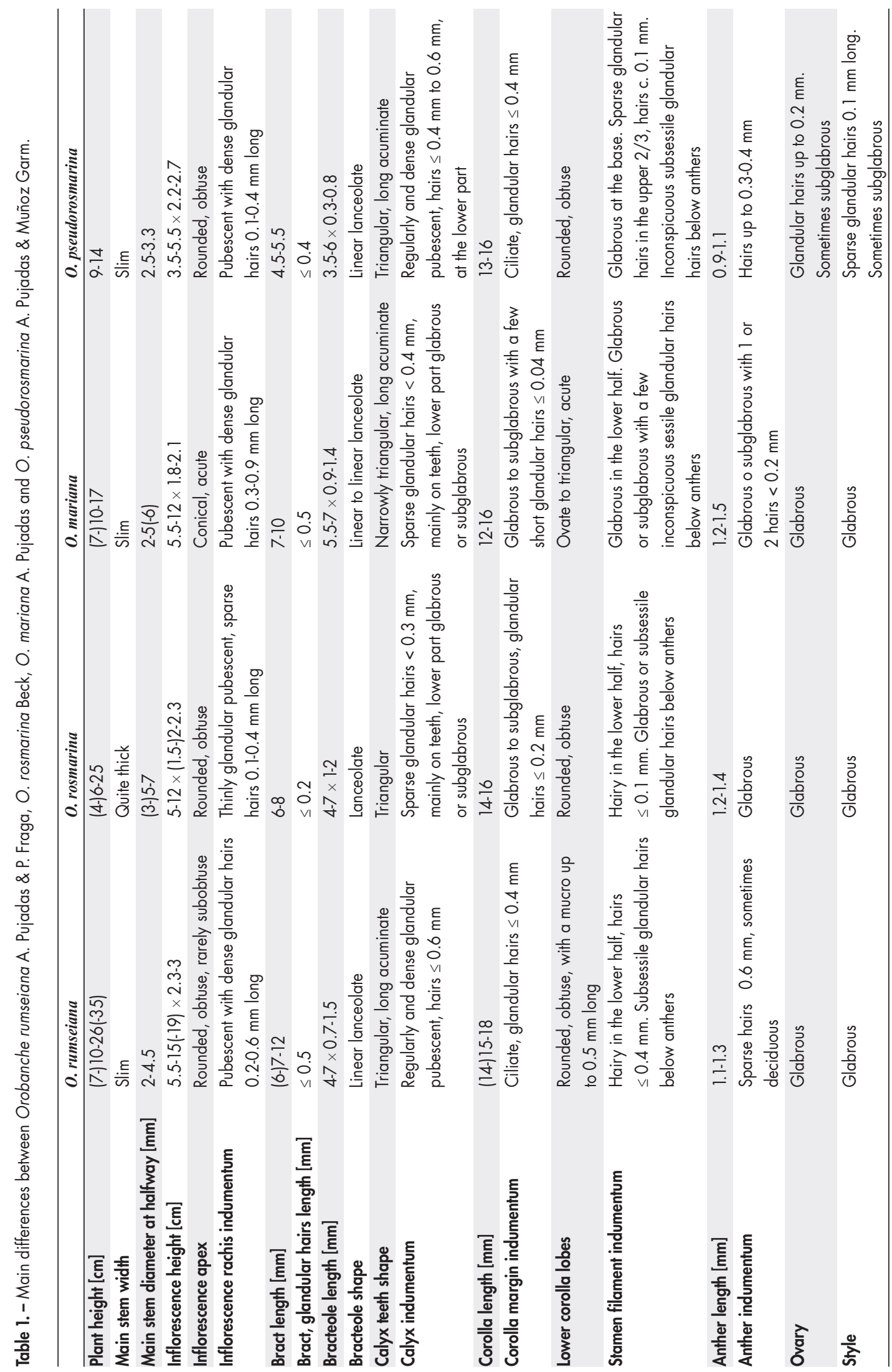


level as Sites of Community Interest (SCI) within the Natura 2000 Network, none of these legal instruments provides integral protection against threats such as invasive species or changes in land use. For these reasons, urgent conservation measures should be implemented to protect the populations and natural habitats of $O$. rumseiana.

Iconography. - BECKETT (1993: tab. 61, 4, sub Orobanche rosmarina).

Taxonomy. - Within the subgen. Trionychon, O. rumseiana presents a number of features, described in the diagnosis, that are not normally found in any other taxon in this group. Although it has certain similarities with O. rosmarina, O. mariana and $O$. pseudorosmarina (see Appendix 1 for the studied specimens), important morphological differences between these taxa warrant its recognition at species level (Table 1). Thus, it can be discriminated from these allied taxa mainly by the obtuse corolla lobes with a mucro up to $0.7 \mathrm{~mm}$ long and also by the stamen filaments, which are hairy in the lower half, with hairs up to $0.4 \mathrm{~mm}$ long.

Furthermore, certain characteristics distinguish it from O. rosmarina: its thinner stem, $2-4.5 \mathrm{~mm}$ diameter at medium height; densely glandular pubescent rachis (hairs 0.2-0.6 mm long); bracts with longer glandular hairs $(\leq 0.5 \mathrm{~mm})$; lanceolate linear bracteoles, usually narrower $(0.7-1.5 \mathrm{~mm})$; calyx teeth more acuminate and with denser glandular indumentum; glandular ciliate corolla margins (hairs $\leq 0.4 \mathrm{~mm}$ ).

The differences with $O$. mariana are as follows: wider inflorescence (2.3-3 cm) with a more rounded and obtuse apex, rarely subobtuse; uniform and densely glandular pubescent calyx in the upper half; glandular ciliate corolla margins (hairs $\leq 0.4 \mathrm{~mm}$ ); anthers usually shorter (1.1-1.3 mm) and ciliate at the base with a few long hairs $(\leq 0.6 \mathrm{~mm})$, sometimes deciduous.

The differences with $O$. pseudorosmarina are as follows: a taller habit $(\leq 26(-35) \mathrm{cm})$; rachis with longer glandular hairs $(\leq 0.6 \mathrm{~mm})$; longer bracts $[(6) 7-12 \mathrm{~mm}]$; bracteoles usually wider $(0.7-1.5 \mathrm{~mm})$; longer corolla $(\leq 18 \mathrm{~mm})$; anthers usually longer (1.1-1.3 mm); ovary and style glabrous.

In addition to the morphological differences, these group species also display a distinct geographic distribution pattern. Thus, $O$. rumseiana is restricted to the eastern Balearic Islands, $O$. rosmarina is distributed in the southwest of continental Europe, O. mariana has only been reported in Sierra Morena (southwest of the Iberian Peninsula), and $O$. pseudorosmarina is distributed throughout coastal areas of the Eastern Mediterranean region.

Paratypi. - SPAIN. Balearic Islands, Majorca: Pollença, Cala Sant Vicenç, camí cap a la Punta de Ses Coves Blanques, $39^{\circ}$ 55'36.17'”N 303'01.60'"E, $72 \mathrm{~m}$, sobre Rosmarinus officinalis, 24.VII.2002, A. Pujadas s.n. (COA [49187]); Pollença, Cala Sant Vicenç, c. Punta de Ses Coves Blanques, 3955' 51.56”'N
303'18.46"E, 103 m, sobre Rosmarinus officinalis, 2.IV.2003, A. Pujadas s.n. (COA [49185]); Mallorca, sobre Rosmarinus officinalis, VI.1979, J. Orell 1345 (Herb. Orell-Casasnovas); Flora majoricensis 612, supra Rosmarinum legita, 6.X.1946, Palau Ferrer s.n. (MA [114767]). Minorca: Ciutadella, Macarella, 31SEEE80 3215, 50 m, sobre Rosmarinus officinalis, 2.V.2010, P. Fraga s.n. (COA [49324]); Es Mercadal, Tirant, 31TEE948340, 40 m, sobre Rosmarinus officinalis, 14.V.2010, P. Fraga s.n. (COA [49325]); Es Mercadal, Cala Blanca, 31TEE968319, 2 m, sobre Rosmarinus officinalis, 15.V.2010, P. Fraga s.n. (COA [49326]); Ciutadella, Es Banyuls, 31SEE761202, 5 m, sobre Rosmarinus officinalis, 17.V. 2010, P. Fraga s.n. (COA [49327]); Es Mercadal, Sa Mola de Fornells, Cala Pudent, 31TEE988338, 10 m, sobre Rosmarinus officinalis, 25.V. 2010, P. Fraga s.n. (COA [49328]); Son Olivar, Trabaluger [Trebalúger], 31SEE8823, 100 m, 22.IV.1957, P. Montserrat s.n. (JACA [155857]); [probably O. rumseiana] Alayor, Son Sancho, 20.V.1898, A. Pons y Guerau s.n. (MA [435481]).

\section{Acknowledgements}

We wish to thank Santos Cabello for the Latin diagnosis. We are very grateful to the keepers and staff of the $\mathrm{ABH}, \mathrm{BC}$, $\mathrm{BCN}, \mathrm{BM}, \mathrm{COFC}, \mathrm{COI}$, "H. Col.legi Oficial de Farmacèutics de les Illes Balears", HJBS, "H. Orell-Casasnovas", JACA, JE, LISI, LISU, MA, MAF, MGC, MPU, MUB, SEV, UIB, $\mathrm{VAB}, \mathrm{VAL}, \mathrm{W}$ and WU herbaria for the studied material.

\section{References}

BARCEló I COMBIS, F. (1879-1881). Flora de las Islas Baleares, seguida de un diccionario de los nombres baleares, castellanos y botánicos de las plantas espontáneas y cultivadas. Palma de Mallorca.

BeCKett, E. (1993). Ill. Fl. Mallorca. Editorial Moll.

Bolòs, O. \& J. Vigo (1996). Fl. Països Catalans 3. Barcino.

Carlón, L., G. Gómez-Casares, M. Laínz, G. Moreno-Moral, Ó. SÁNCHEZ-PEDRAJA \& G. M. SCHNEEWEISS (2005). Más, a propósito de algunas Orobanche L. y Phelipanche Pomel (Orobanchaceae) del oeste del Paleártico. Doc. Jard. Bot. Atlántico 3.

Carlón, L., G. Gómez-Casares, M. Laínz, G. Moreno-Moral, Ó. SÁnchez-Pedraja \& G. M. Schneeweiss (2008). Más, a propósito de algunas Phelipanche Pomel, Boulardia F. W. Schultz y Orobanche L. (Orobanchaceae) del oeste del Paleártico. Doc. Jard. Bot. Atlántico 6.

Crespo, M. B. \& A. J. Pujadas-Salvà (2006). Notas sobre Phelipaea reuteriana Rchb. f. (Orobanchaceae). Fl. Montiber. 33: 27-31.

Domina, G. (2010). Orobanchaceae. In: GReuter, W. \& E. von RAAB-STraube (ed.), Euro+Med Notulae, 4. Willdenowia 39: 331.

Domina, G. \& E. von RAAB-STRAube (2010). Orobanchaceae. In : Euro+Med Plantbase - the information resource for Euro-Mediterranean plant diversity [http://ww2.bgbm.org/EuroPlusMed]. 
FOLEY, M. J. Y. (2001a). Orobanchaceae in the "Flora iberica" area: new taxa, excluded taxa, and typification. Anales Jard. Bot. Madrid 58: 223-233.

Foley, M. J. Y. (2001b). Orobanche L. In: Paiva, J., F. SAles, I. C. Hedge, C. Aedo, J. J. Aldasoro, S. Castroviejo, A. Herrero \& M. Velayos (ed.), Fl. Iber. 14: 32-72. Real Jardín Botánico, CSIC, Madrid.

Fraga i Arguimbau, P., C. Mascaró-Sintes, D. Carreras-Martí, Ò. García-Febrero, X. Pallicer-Allès, M. Pons-Gomila, M. Seonne-Barber \& M. Truyol-Olives (2004). Catàleg de la flora vascular de Menorca. Institut Menorquí d'Estudis, Maó.

GIL, L. \& L. Llorens (1999). Claus de determinació de la Flora Balear. El Gall Editor \& Govern Balear, Consellería d'Educació, Cultura i Sports, Palma de Mallorca.

Greuter, W., H. M. Burdet \& G. Long (1989). Med-checklist. Vol. 4 (Lauraceae-Rhamnaceae). Conservatoire et Jardin Botaniques de la Ville de Genève.

IUCN (2001). IUCN Red List Categories. Version 3.1. Prepared by the IUCN Species Survival Commission. World Conservation Union, Gland.

Knoche, H. (1922). Flora Balearica. Etude phytogéographique sur les îles Baléares 2. Montpellier.

Marès, P. \& G. VigineIX (1880). Catalogue raisonné des plantes vasculaires des Iles Baléares. G. Masson.

Pujadas-SalvÀ, A. J. (2001). Aportació al coneixement del gènere Orobanche L. als Països Catalans. Orsis 16: 71-88.

Pujadas-Salvà, A. J. (2002). Orobanche L. In : LóPez-SÁEz, J. A., P. Catalán \& Ll. SÁez (ed.), Plantas parásitas de la Península Ibérica e Islas Baleares: 348-440. Mundi-Prensa.
PujadAs-SalvÀ, A. J. (2006). Nuevas combinaciones nomenclaturales y aportaciones florísticas en el género Orobanche L. (Orobanchaceae). Lagascalia 26: 246-248.

Pujadas-Salvà, A. J. (2007). Orobanche mariana A. Pujadas (Orobanchaceae) sp. nov. para el sur de la Península Ibérica. Acta Bot. Malac. 32: 269-274.

Pujadas-Salvà, A. J. \& M. B. Crespo (2004). A new species of Orobanche (Orobanchaceae) from south-eastern Spain. Bot. J. Linn. Soc. 146: 97-102.

Pujadas-Salvì, A. J. \& J. F. Muñoz-Garmendia (2010). Orobanche pseudorosmarina A. Pujadas et Muñoz Garm. sp. nov. (Orobanchaceae) from the eastern Mediterranean region. Acta Bot. Croat. 69: 1-6.

Pujadas-Salvì, A. J., D. Rubiales-Olmedo \& M. LóPez-Martínez (2005). Orobanche L. (Orobanchaceae) sect. Trionychon Wallr., en Andalucía II: Orobanche rosmarina Beck. Acta Bot. Malac. 30: 49-54.

Rivas-Martínez, S., T. E. Díaz, F. Fernández-González, J. Izco, J. LoIDI, M. Lousã \& A. PenAs (2002). Vascular plant communities of Spain and Portugal. Addenda to the Syntaxonomical Checklist of 2001. Itin. Geobot. 15: 5-922.

Rivas-Martínez, S., F. Fernández-GonzÁLez, J. Loidi, M. Lousã \& A. Penas (2001). Syntaxonomical checklist of vascular plant communities of Spain and Portugal to association level. Itin. Geobot. 14.

Rodríguez-Femenías, J. J. (1904). Flórula de Menorca. Maó.

Rosselló, J. A. \& L. SÁEz (2000). Index Balearicum: An annotated check-list of the vascular plants described from the Balearic Islands. Collect. Bot. (Barcelona) 25. 
Appendix 1. - Studied material of Orobanche rosmarina Beck, O. mariana A. Pujada and O. pseudorosmarina A. Pujadas \& Muñoz Garm.

O. rosmarina Beck in Oesterr. Bot. Z. 70(9/12): 243. 1921.

Portugal. Estremadura: S. de Arrábida, 1848-1850 [1852], Dr. Welwitsch s.n. (BM [574992]); Serra da Arrábida, rarior, rarius adhuc radices Quercus humilis, in Serra de Montejunto, ubi etiam ad Rosmarinus, V-VI s.a., Welwitsch s.n. (LISU [P34461]); Serra da Arrábida, Casal da Pimenta, 15.IV.1903, A. Guimarães s.n. (LISU [P34460]); Serra da Arrábida, Casal do Pimenta, sobre Rosmarinus, IV.1903, A. Guimarães 2270 (LISU [P34459]); Serra da Arrábida, in collib. calcar. pr. Freitas, 150 m, 20.V. 1936, W. Rothmaler, Fl. Lusit. 419 (JE); Serra da Arrábida, in rupestribus inter Portinho et Torres, 21.V.1936, W. Rothmaler, Fl. Lusit. 515 (JE)

O. mariana A. Pujadas in Acta Bot. Malac. 32: 270. 2007.

SpaIN. Córdoba: Obejo, Río Guadalbarbo, cerca del Cortijo del Cura, 30SUH4117, 290 m, sobre Rosmarinus officinalis, con Orobanche latisquama, 18.V.2001, D. Rubiales \& A. Pujadas s.n. (COA [31029]); Alcaracejos, La Chimorra, 333927 / 4230 064, 652 m, 15.V.2007, E. Reyes Sepúlveda s.n. (COA [376 50]); Córdoba, Los Villares, 342052 / 4205742, 28.V.2007, E. Reyes Sepúlveda s.n. (COA [47804]). Sevilla: El Real de la Jara, Sierra del Pimpollar, Cortijo de las Águilas, 30SQC 5605, 740 m, 19.VI.1997, J. M. Delgado \& M. López s.n. (COA [23756]); El Real de la Jara, Sierra del Pimpollar, Cortijo de las Águilas, 30SQC5605, 740 m, sobre Rosmarinus?, 9.VII.1997, M. López \& A. Pujadas s.n. (COA [23755]).
O. pseudorosmarina A. Pujadas \& Muñoz Garm. in Acta Bot. Croat. 69: 3.2010.

Croatia. Dalmatia: Insel Brazza, s.d., Hb. Portenschlag (W); Scoglie San Andrea, 26.V.1876, G. C. Spreitzenhofer s.n. (WU [77 91]); Insel Lissa, bei Comisa, 23.V.1901, A. Ginzberger s.n. (WU); Comisa, Insel Lissa, 19.V.1905, E. Kindt s.n. (WU); Insel Busi, Oberhalb Porto Basi, machie, 20-26.V.1911, A. Ginzberger \& A. Teyber s.n. (WU); Insel Lissa, Umgebung von Comisa, schiff am der Nordseite der Bricht, auf Rosmarinus officinalis, 21.V. 1911, A. Ginzberger \& A. Teyber s.n. (WU); Insel San Andrea westl. von Lissa, Oberhalb Porto Slatina, 6-9.VI.1911, A. Ginzberger \& A. Teyber s.n. (WU); Insel San Andrea westl. Von Lissa, 6-9.VI.1911, A. Ginzberger \& A. Teyber s.n. (WU). 